\title{
Airborne high spectral resolution lidar observation of pollution aerosol during EUCAARI-LONGREX
}

\author{
S. Groß ${ }^{1}$, M. Esselborn ${ }^{1, *}$, F. Abicht ${ }^{1, * *}$, M. Wirth ${ }^{1}$, A. Fix ${ }^{1}$, and A. Minikin ${ }^{1}$ \\ ${ }^{1}$ Deutsches Zentrum für Luft- und Raumfahrt (DLR), Institut für Physik der Atmosphäre (IPA), Münchner Str. 20, \\ Oberpfaffenhofen, 82234 Weßling, Germany \\ *now at: European Southern Observatory, Karl-Schwarzschild-Str. 2, 85748 Garching, Germany \\ *** now at: Max-Born-Institut, Max-Born-Str. 2a, 12489 Berlin, Germany
}

Correspondence to: S. Groß (silke.gross@dlr.de)

Received: 12 July 2012 - Published in Atmos. Chem. Phys. Discuss.: 11 October 2012

Revised: 31 January 2013 - Accepted: 20 February 2013 - Published: 1 March 2013

\begin{abstract}
Airborne high spectral resolution lidar observations over Europe during the EUCAARI-LONGREX field experiment in May 2008 are analysed with respect to the optical properties of continental pollution aerosol. Continental pollution aerosol is characterized by its depolarisation and lidar ratio. Over all, the measurements of the lidar ratio and the particle linear depolarization ratio of pollution aerosols provide a narrow range of values. Therefore, this data set allows for a distinct characterization of the aerosol type "pollution aerosol" and thus is valuable both to distinguish continental pollution aerosol from other aerosol types and to determine mixtures with other types of aerosols.
\end{abstract}

\section{Introduction}

Aerosol particles are a main component of the atmosphere and affect the Earth's climate system in two different ways. They scatter and absorb the solar and terrestrial radiation, and they act as cloud condensation nuclei and for this reason influence cloud properties. According to the findings of the IPCC (Foster et al., 2007) the current level of scientific understanding of the impact of aerosols on the global climate system is considered as medium to low. The effect of aerosols depends on the spatial and vertical distribution of aerosols, on their chemical and microphysical properties, as well as on the reflectance of the underlying surface and the presence of clouds. As aerosols show a large spatial and temporal variability their impact on regional scale can be quite different (IPCC, 2007). To improve our knowledge on the impact of aerosols on the Earth's climate system, long-term observations and coordinated observations during intensive field campaigns (such as closure studies, Quinn et al., 1996) are crucial. Furthermore, the presence of aerosols in the lower atmosphere plays a significant role in air quality and health considerations.

The European integrated project on Aerosol Cloud Climate and Air Quality Interactions (EUCAARI) was supported by the European Commission under the Sixth Framework Programme with the aim of investigating the role of aerosols on climate and air quality (Kulmala et al., 2009). Embedded in the EUCAARI intensive observational period, the aircraft field experiment EUCAARI-LONGREX (Long Range Experiment) was conducted in May/June 2008 to investigate physical and chemical properties of atmospheric aerosols within the free troposphere and the boundary layer on European scale. Essential activities of this experiment included a comprehensive characterization of main aerosol types over Europe and their exchange between boundary layer and free troposphere. Spatial and temporal gradients of aerosol loading were investigated to evaluate aerosol sources and sinks. Moreover, the experiment included a closure study of aerosol optical thickness observed from ground, sky and space (Kulmala et al., 2011). During EUCAARI-LONGREX two research aircraft were based at the airport of Oberpfaffenhofen, Germany. The Falcon 20 jet, operated by the German Aerospace Centre (DLR), equipped with a nadir viewing HSRL (High Spectral Resolution Lidar) and a comprehensive in-situ instrumentation generally focused on the upper troposphere and occasionally guided the low flying British 
BAe-146 (FAAM, Facility for Airborne Atmospheric Measurements) into specific aerosol layers. Above ground observation sites and other regions of particular interest the Falcon flew stacked vertical profiles in order to sample the atmospheric column from high altitude down to the boundary layer.

Airborne lidar instruments are particularly suitable for observing the horizontal and the vertical distribution of aerosol structures on a regional scale. The advantage of HSRL over normal backscatter-only lidar is the ability to directly measure the extinction-to-backscatter ratio (lidar ratio) of aerosols (Shipley et al., 1983; Shimizu et al., 1983). The value of this quantity depends on the physical properties of aerosols, namely the size distribution, the complex index of refraction and the morphology (Evans, 1988). It does not depend on its concentration. Current spaceborne lidars such as the Cloud Aerosol Lidar and Infrared Pathfinder Satellite Observation (CALIPSO) instrument (Winker et al., 2007) provide global coverage but only measure the attenuated backscatter signal. Hence the retrieval of vertical aerosol backscatter and extinction profiles relies on a-priori assumptions on the lidar ratio. Therefore, the accuracy of the retrieved extinction profile is determined by the assumed lidar ratio (e.g. Wandinger et al., 2010). The results of airborne HSRL measurements can be helpful to improve the informative content of spaceborne measurements. This paper focuses on the analysis of the airborne HSRL measurements of the aerosol lidar ratio and the particle linear depolarisation ratio taken during the first half of EUCAARI-LONGREX (6 May to 14 May). Both quantities only depend on the aerosol type and can be used to classify different types of aerosol (Groß et al., 2011, 2012; Burton et al., 2012).

\section{Methods}

\subsection{DLR Falcon HSRL}

During the EUCAARI-LONGREX field campaign a HSRL system was operated on board the DLR Falcon research aircraft. This system was originally developed as an airborne demonstrator for a possible future spaceborne multiwavelength differential absorption lidar (DIAL) for water vapour measurements at $935 \mathrm{~nm}$ (WALES - Wirth et al., 2009). In addition to the $\mathrm{H}_{2} \mathrm{O}$-channels, the system provides backscatter and depolarisation channels at $1064 \mathrm{~nm}$ and $532 \mathrm{~nm}$ for aerosol characterization. At $532 \mathrm{~nm}$ a molecular channel is implemented for the HSRL measurements. The HSRL receiver channel was already successfully deployed during former field campaigns. A detailed technical description of the HSRL system and a presentation of its measurements can be found by Esselborn et al. (2008) and Esselborn et al. (2009). Typically, the system allows signal integration times as short as a few seconds with an acceptable statistical error of less than $5 \%$ in the backscatter data. The vertical resolution of the profiles is $15 \mathrm{~m}$ for all backscatter and depolarisation data. For the extinction and lidar ratio profiles the vertical resolution is $360-700 \mathrm{~m}$. Relative systematic errors of the backscatter measurements are typically $4 \%$ to $8 \%$, statistical errors are typically $<1 \%$ and therefore negligible. For the extinction measurements the relative systematic errors are usually less than $5 \%$, so that statistical errors of typically $5 \%$ to $20 \%$ are dominant. Relative systematic errors of the depolarisation measurements are primarily due to mechanical accuracy of the calibration measurement and result in a relative error of the particle linear depolarisation ratio of the order of $10 \%$ to $16 \%$. For detailed information on the error calculation see Esselborn et al. (2008) and Freudenthaler et al. (2009). Because of eye safety regulations in the considerably busy airspace over Europe, HSRL measurements at $532 \mathrm{~nm}$ were restricted to places which were cleared by air traffic control.

\subsection{Meteorological conditions during EUCAARI}

The synoptic situation of the first half of the EUCAARILONGREX field campaign, from 6-14 May 2008, was dominated by a persistent high-pressure blocking system, remaining almost stationary over southern Sweden and Denmark (Fig. 1). Due to the stability of the system during the main part of the campaign, a constant east-west transport of airmass could be observed in Central Europe. The absence of precipitation during this period favoured the accumulation of pollution aerosol in the continental boundary layer. Figure 1 shows the typical meteorological situation during the first half of the campaign exemplarily for the geopotential and wind at $850 \mathrm{hPa}$ on 10 May 2008 .

From 11 May to 14 May the high-pressure system moved westward, north-east of the British Islands and started to decay on 14 May. The second half of the field campaign was characterized by advection mostly from northerly directions. A detailed description of the meteorological situation during the EUCAARI-LONGREX campaign can be found by Hamburger et al. (2011).

Figure 2 shows a backward trajectory analysis for the five Falcon flight missions during the first half of the field campaign. The backward trajectories show a circulated flow pattern and advection from eastern directions. The trajectories were calculated with the Hybrid Single Particle Lagrangian Integrated Trajectory (HYSPLIT) model (Draxler and Rolph, 2012) and the NCEP Global Data Assimilation System (GDAS) data, and start at the times and places the HSRL measurements were analysed. The duration is five days backward for all trajectories.

\subsection{Flight missions during EUCAARI}

A total of 48 flight hours were performed during 15 flight missions (Hamburger et al., 2011, 2012). Due to the persistent high pressure system transporting air masses in westerly 


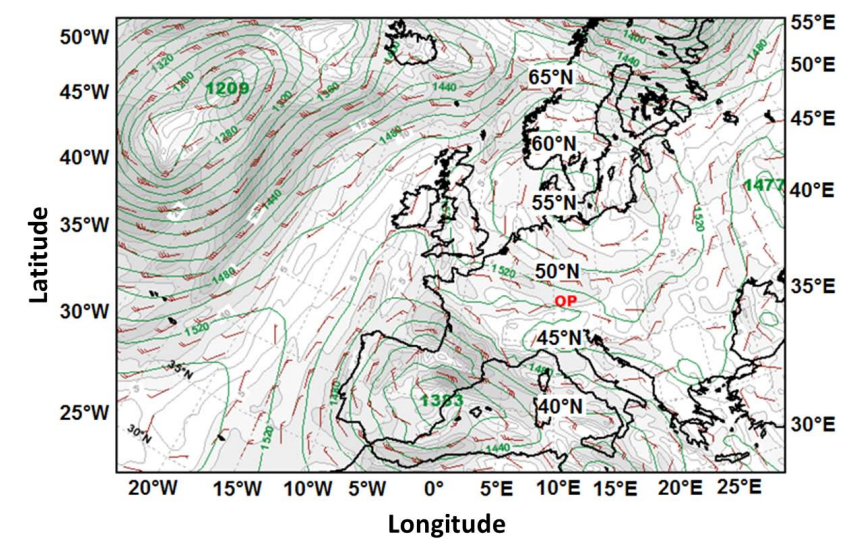

Fig. 1. Geopotential and wind field at $850 \mathrm{hPa}$ on 10 May 2008. OP marks the airport of Oberpfaffenhofen.

directions, the flights were restricted to areas north of the Alps. Figure 3 shows a compilation of all Falcon flight missions performed during EUCAARI-LONGREX.

During EUCAARI-LONGREX the German Falcon operated out of Oberpfaffenhofen airport $\left(48.08^{\circ} \mathrm{N}, 11.27^{\circ} \mathrm{W}\right)$. The flight patterns of the Falcon were designed for lidar observation at high altitude and subsequent in situ profiling over the instrumented ground stations and other specific regions identified by lidar.

\section{Results and discussion}

Due to the meteorological conditions, only measurements during the first half of the campaign are used for the characterization of pollution aerosols. This restriction is necessary to make sure that pollution aerosol was the dominant, if not the only, aerosol type within the observed aerosol layers, and to ensure high aerosol load within these aerosol layers to achieve high accuracy of the measurements with resulting small uncertainties. We present a case study on 14 May 2008 which shows an exemplary analysis of the measurement data since this day has extensive data analyses in terms of a closure study, i.e. lidar measurements, vertical profiling of in-situ measurements, and satellite (PARASOL) overpass (Kulmala et al., 2011).

\subsection{Case study of pollution aerosol on 14 May 2008}

The flight mission on 14 May 2008 was dedicated to coordinated observations of a pollution aerosol plume west of Ireland. To ensure maximum flight endurance west of the coast of Ireland, the Falcon aircraft was transferred to Shannon/Ireland the day before and performed a local flight on 14 May 2008. (The Falcon flight track is shown in Fig. 3 in the yellow line). The location west of the Irish coast was chosen due to a forecasted pollution transport event. Backward trajectories (Fig. 2 red line) show that the observed
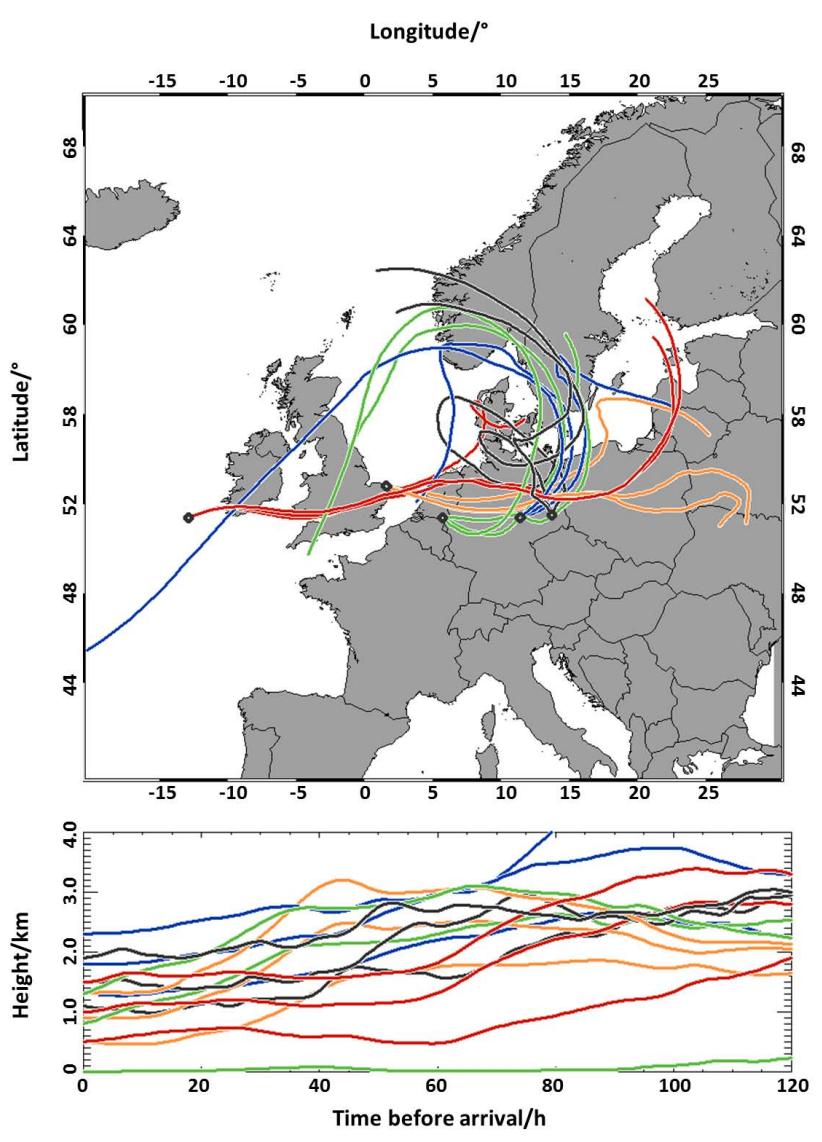

Fig. 2. 5-day backward trajectories for the locations of flight missions during the first half of the EUCAARI-LONGREX field campaign. The trajectories start in height levels identified by the lidar measurements and considered as pollution aerosols (also see Table 1).

air masses were transported from easterly directions, crossing over Northern Germany, the Netherlands, Southern England and Southern Ireland. The mean flight altitude during this flight leg was $10 \mathrm{~km}$. The colour coding in Fig. 4 indicates the column integrated aerosol optical depth (AOD) between flight altitude and ground along the flight track. It is a measure of the column integrated aerosol load and indicates to which degree aerosols prevent the transmission of light through the atmosphere by scattering and absorption. An AOD of less than 0.1 indicates clear sky conditions whereas an AOD of 1 indicates hazy conditions. Along the flight track the AOD ranged between $\sim 0.1$ near the Irish Coast and $\sim 0.5$. The AOD was significantly higher in the south-eastern part of the flight leg.

The lidar backscatter ratio (Fig. 5) indicated the aerosol layers along the flight path, in the marine boundary layer and in the free troposphere up to about $4.5 \mathrm{~km}$ altitude. The aerosol structure was inhomogeneous with several elevated layers. 


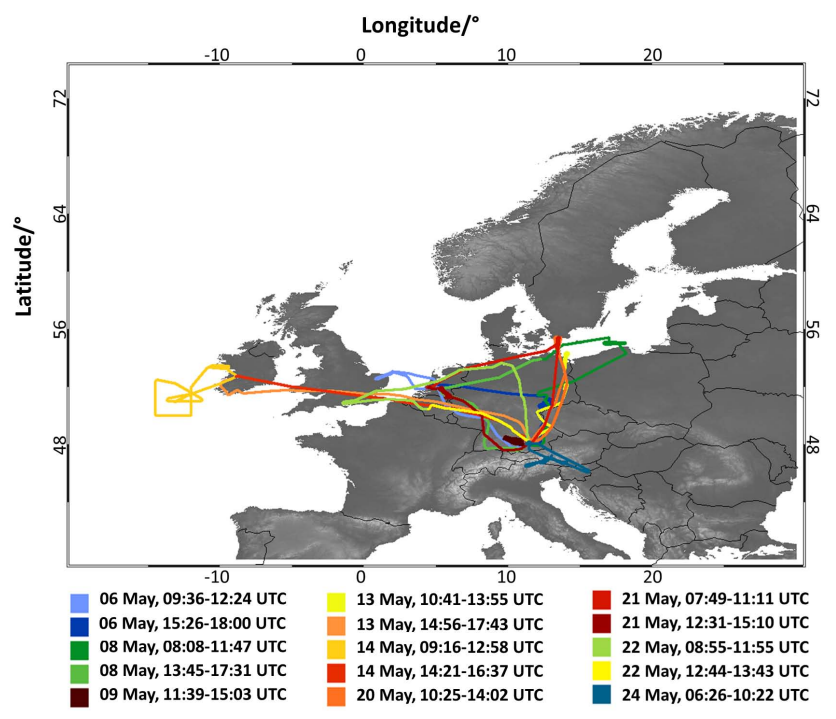

Fig. 3. Falcon flight tracks during EUCAARI-LONGREX.
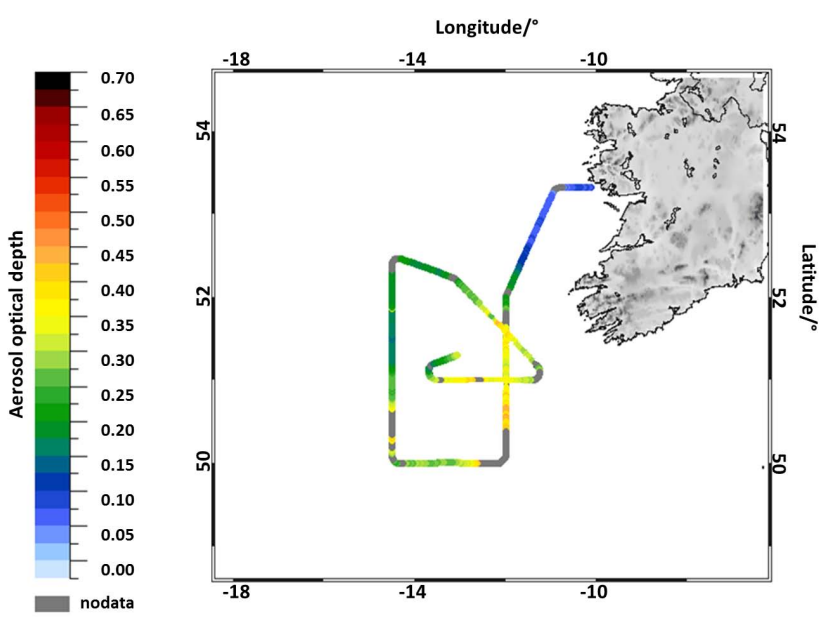

Fig. 4. AOD at $532 \mathrm{~nm}$ along the Falcon flight track south-west of Ireland on 14 May 2008. "Nodata" marks areas in which the calculation of AOD was prevented by clouds, or by biased measurements caused by spiralling.

In order to allow the analysis of air masses of pure continental origin having not being influenced by marine boundary layer and/or advection we used a combination of backtrajectories, calculated with the Lagrangian Analysis Tool (LAGRANTO) (Wernli and Davies, 1997; Wernli, 1997), and European Center of Medium-Range Weather Forecast (ECMWF) data. For the definition of the source strength of anthropogenic emission along each trajectory the Emissions Database for Global Atmospheric Research (EDGAR) was used. A detailed description of this procedure as well as an application of trajectory analysis to in-situ observations on board the FALCON aircraft can be found by Hamburger et

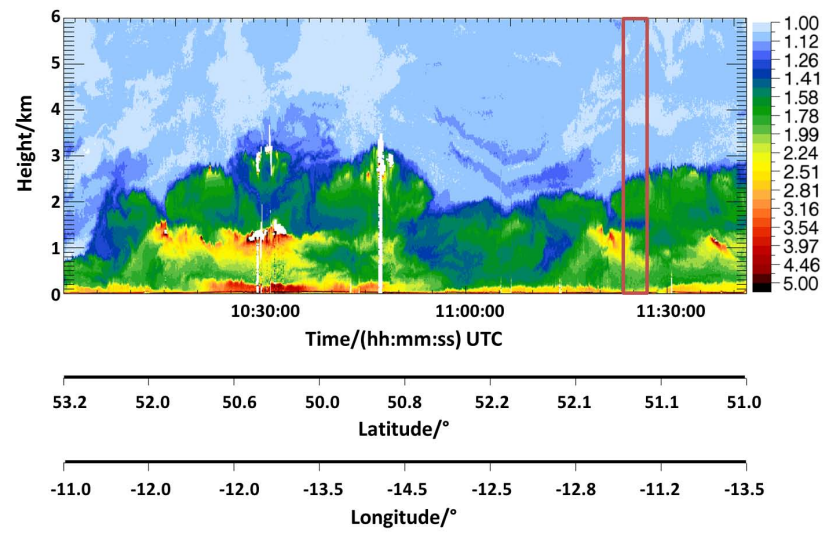

Fig. 5. Aerosol distribution shown as cross-section of the backscatter ratio at $532 \mathrm{~nm}$ along the flight track on 14 May 2008 shown in Fig. 4.

al. (2012). The HSRL data was filtered according to the following criteria:

1. The residence time of the aerosol over the European Continent without Scandinavia is larger than $36 \mathrm{~h}$.

2. During these $36 \mathrm{~h}$ the trajectories stayed below $2.5 \mathrm{~km}$ (750 hPa).

3. During the last $12 \mathrm{~h}$ before measurements the trajectories have been above $0.8 \mathrm{~km}(930 \mathrm{hPa})$ over ocean.

Furthermore, we choose measurement periods with sufficient aerosol load and vertical homogeneity of the layering to avoid uncertainties due to inhomogeneity in the averaged data. Accordingly, a part in the middle of the flight region was chosen for a detailed study, which is indicated in Fig. 5 by the red rectangle. The mean profiles of the particle backscatter coefficient, the particle extinction coefficient, the particle lidar ratio and the particle linear depolarisation ratio are shown in Fig. 6.

From these profiles, a two layer structure of the selected time period is observable which is also supported by backward trajectories (not shown here). The lower layer, which is mainly influenced by polluted aerosols from source regions over England, reaches up from about 0.9 to about $1.4 \mathrm{~km}$ and shows a mean lidar ratio of $60 \pm 5 \mathrm{sr}$ and a mean particle linear depolarisation ratio of $5 \pm 1 \%$, the upper layer (from about $1.7 \mathrm{~km}$ to $2.5 \mathrm{~km}$ ) which is mainly influenced from European continental aerosols shows a mean lidar ratio of $67 \pm 5 \mathrm{sr}$ and a mean value of the particle linear depolarisation ratio of about $6 \pm 1 \%$. Below about $0.9 \mathrm{~km}$ the lidar ratio strongly decreases. This decrease may be caused by marine influenced air masses. The mean particle extinction coefficient in the lower layer is about $0.2 \mathrm{~km}^{-1}$, whereas the maximum value of the particle extinction coefficient in the upper layer is only $0.1 \mathrm{~km}^{-1}$. The latter results are in very good agreement with the vertical profiles of the extinction 
Table 1. Mean lidar ratio (LR) and particle linear depolarisation ratio (PDR) at $532 \mathrm{~nm}$ for the analysed pollution layers shown in Figs. 6 and 7. \pm -values indicate the mean systematic uncertainties.

\begin{tabular}{lllccc}
\hline Date & Location & $\begin{array}{l}\text { Time } \\
\text { (UTC) }\end{array}$ & $\begin{array}{c}\text { Altitude Range } \\
{[\mathrm{km}]}\end{array}$ & $\begin{array}{c}\text { LR } \\
{[\mathrm{sr}]}\end{array}$ & $\begin{array}{c}\text { PDR } \\
{[\%]}\end{array}$ \\
\hline 6 May & Southeast Coast England & $10: 56-11: 06$ & $0.9-1.7$ & $56 \pm 6$ & $5 \pm 1$ \\
6 May & Melpitz, Germany & $16: 08-16: 15$ & $1.8-2.3$ & $57 \pm 5$ & $6 \pm 1$ \\
8 May & Cabauw, Netherlands & $14: 45-14: 56$ & $0.5-1.3$ & $52 \pm 4$ & $9 \pm 1$ \\
13 May & Cottbus, Germany & $11: 18-11: 26$ & $1.3-1.6$ & $53 \pm 7$ & $6 \pm 1$ \\
14 May & Irish Coast & $11: 23-11: 26$ & $0.9-1.4$ & $60 \pm 5$ & $5 \pm 1$ \\
\hline
\end{tabular}
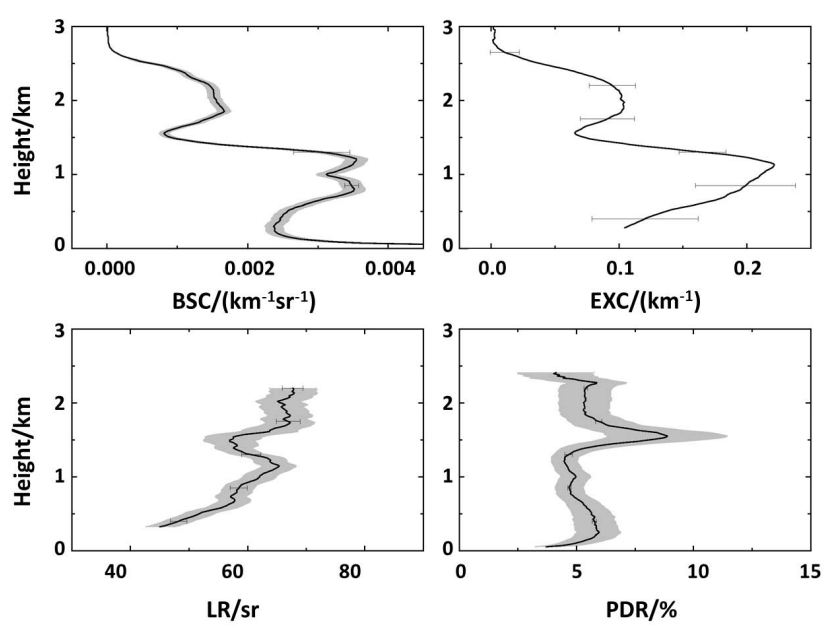

Fig. 6. HSRL vertical profiles of backscatter coefficient (BSC) (upper left panel), extinction coefficient (EXC) (upper right panel), lidar ratio (LR) (lower left panel) and particle linear depolarisation ratio (PDR) (lower right panel) at $532 \mathrm{~nm}$ for the selected flight track south-west of Ireland on 14 May. The grey shaded areas mark the systematic error, the error bars the statistical errors.

coefficient derived from the in situ particle size distribution measurements on board the Falcon aircraft (Kulmala et al., 2011).

\subsection{General findings of all pollution cases}

\subsubsection{Vertical layering}

In the previous subsection we presented an analysis of the case study of 14 May 2008 as an example. Now we consider all analysed lidar measurements of pollution cases during the first half of the EUCAARI-LONGREX campaign. To get an overview of the temporal and spatial distribution of the pollution aerosols Fig. 7 shows vertical profiles of the backscatter coefficient, the extinction coefficient, the lidar ratio and the particle linear depolarisation ratio (all at $532 \mathrm{~nm}$ ) for further four HSRL measurement. The profiles correspond to measurements at the southeast coast of England on 6 May (10:56-11:06 UTC), near Melpitz, Germany, on 6 May (16:08-16:15 UTC), near Cabauw, Netherlands, on
8 May (14:45-14:56 UTC), and near Cottbus, Germany, on 13 May (11:18-11:26 UTC). The backscatter coefficient for these measurements ranged between about $0.001 \mathrm{~km}^{-1} \mathrm{sr}^{-1}$ to about $0.002 \mathrm{~km}^{-1} \mathrm{sr}^{-1}$ within the pollution layers. The corresponding extinction coefficient in the pollution layer was about $0.06-0.1 \mathrm{~km}^{-1}$. The mean values of the lidar ratio (52-60 sr) and the particle linear depolarization ratio (5$9 \%$ ) within the presumed pollution aerosol layers are summarized in Table 1. Considering the lidar ratio and its uncertainties within the corresponding height range we cannot see significant differences for the analysed case studies. However the linear particle depolarization ratio within the considered height range on 8 May (Fig. 7) is higher than the mean values found for the other days. Measurements of the relative humidity from the nearest soundings in space and time (not shown here) show that the relative humidity in the pollution layer on 8 May (14:45-14:56 UTC) was significantly lower $(30-50 \%)$ than on the other days $(60-90 \%)$. The influence of the relative humidity on the aerosol optical properties was e.g. discussed by Zieger et al. (2011). Theoretical model studies (Ackermann, 1998) revealed that low relative humidity leads to lower values of the lidar ratio of pollution aerosols. This result is in good agreement with the findings of the case study of 8 May (14:45-14:56 UTC), where one of the lowest mean values of the lidar ratio was found. However, whether the low relative humidity can explain the difference in the particle linear depolarization ratio or if it is caused by mixing with other aerosol types remains speculation. Simulations or measurements dealing with the dependence of the particle linear depolarization ratio of pollution aerosols on the relative humidity are, to our knowledge, unavailable so far. In the profiles of the intensive optical properties we furthermore see differences to the height ranges above and below the presumed aerosol layers. In the measurements performed on 6 May (10:56-11:06 UTC) north-east of the English coast and on 14 May (11:23-11:26 UTC) south-west of the Irish coast the lidar ratio beneath the pollution layer (below about $1 \mathrm{~km}$ ) decreases with decreasing height. This is most probably an indication for the mixture with marine aerosols which have similar values for the particle linear depolarisation ratio (about $3 \%$ - Groß et al., 2011), but significantly lower values (of about $18 \mathrm{sr}-\mathrm{Groß}$ et al., 2011) 

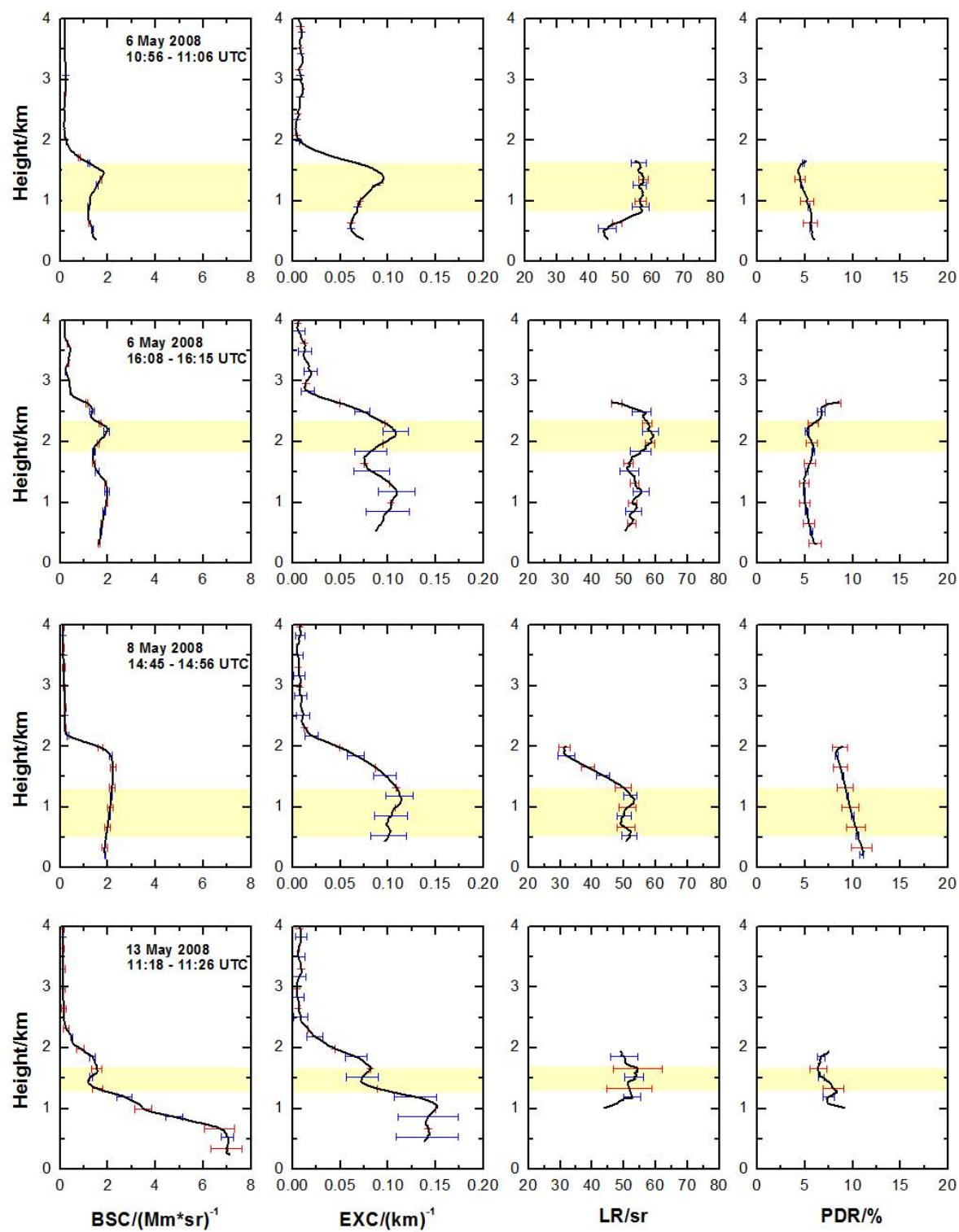

Fig. 7. Vertical profiles of backscatter coefficient (BSC), extinction coefficient (EXC), lidar ratio and particle linear depolarisation ratio (PDR) at $532 \mathrm{~nm}$ for selected measurement periods during the first half of the EUCAARI-LONGREX campaign. The red error bars indicate the systematic errors; the blue error bars indicate the statistical errors. Height levels meeting the criteria for pollution influenced layers are indicated by the light yellow.

for the lidar ratio. On 8 May (14:45-14:56 UTC) the lidar ratio above the pollution layer significantly decreases. This decrease may be caused by mixing with less absorbing background aerosols (Tesche et al., 2007). A similar signature could also be observed by Hänel et al. (2012) above pollution aerosol layers over and near Beijing.

\subsubsection{Optical properties}

Considering all HSRL measurements during the first half of the EUCAARI-LONGREX campaign which achieve the criteria specified in Sect. 3.1 we found a mean lidar ratio of about $56 \mathrm{sr}$ and a mean particle linear depolarization ratio of about $6 \%$ for anthropogenic pollution aerosols. The lidar ratio in the presumed pollution aerosol layers ranged between $33 \mathrm{sr}$ and $72 \mathrm{sr}$, and the particle linear depolarisation ratio showed values between $3 \%$ and $11 \%$. The mean values of both quantities and their statistical information for the different measurement days are summarised in Table 2 and illustrated in Fig. 8. Figure 8a shows the lidar ratio plotted against the particle linear depolarisation ratio for selected flight tracks according to the trajectory criteria described in Sect. 3.1. The grey dots show the results of all measurement 
Table 2. Lidar ratio (LR) and particle linear depolarisation ratio (PDR) at $532 \mathrm{~nm}$, and their statistical information determined from analysed Falcon flights. $Q_{0.25}$ and $Q_{0.75}$ indicate the 1 st and 3rd Quartile.

\begin{tabular}{lcccc|cccc}
\hline Date & \multicolumn{3}{c}{ LR } & \multicolumn{5}{c}{ PDR } \\
\cline { 2 - 9 } & $\begin{array}{c}\text { mean } \pm \text { std } \\
{[\mathrm{sr}]}\end{array}$ & $\begin{array}{c}\text { Range } \\
{[\mathrm{sr}]}\end{array}$ & $\begin{array}{c}Q_{0.25} \\
{[\mathrm{sr}]}\end{array}$ & $\begin{array}{c}Q_{0.75} \\
{[\mathrm{sr}]}\end{array}$ & $\begin{array}{c}\text { mean } \pm \text { std } \\
{[\%]}\end{array}$ & $\begin{array}{c}\text { Range } \\
{[\%]}\end{array}$ & $\begin{array}{c}Q_{0.25} \\
{[\%]}\end{array}$ & $\begin{array}{c}Q_{0.75} \\
{[\%]}\end{array}$ \\
\hline 6 May & $53 \pm 6$ & $33-69$ & 48 & 56 & $6 \pm 1$ & $3-8$ & 5 & 6 \\
8 May & $59 \pm 5$ & $44-72$ & 56 & 62 & $8 \pm 1$ & $6-11$ & 7 & 8 \\
13 May & $52 \pm 3$ & $42-55$ & 50 & 54 & $6 \pm 1$ & $5-10$ & 6 & 7 \\
14 May & $60 \pm 5$ & $50-70$ & 59 & 63 & $6 \pm 1$ & $5-9$ & 6 & 7 \\
Over all & $56 \pm 6$ & $33-72$ & 51 & 61 & $6 \pm 1$ & $3-11$ & 5 & 7 \\
\hline
\end{tabular}
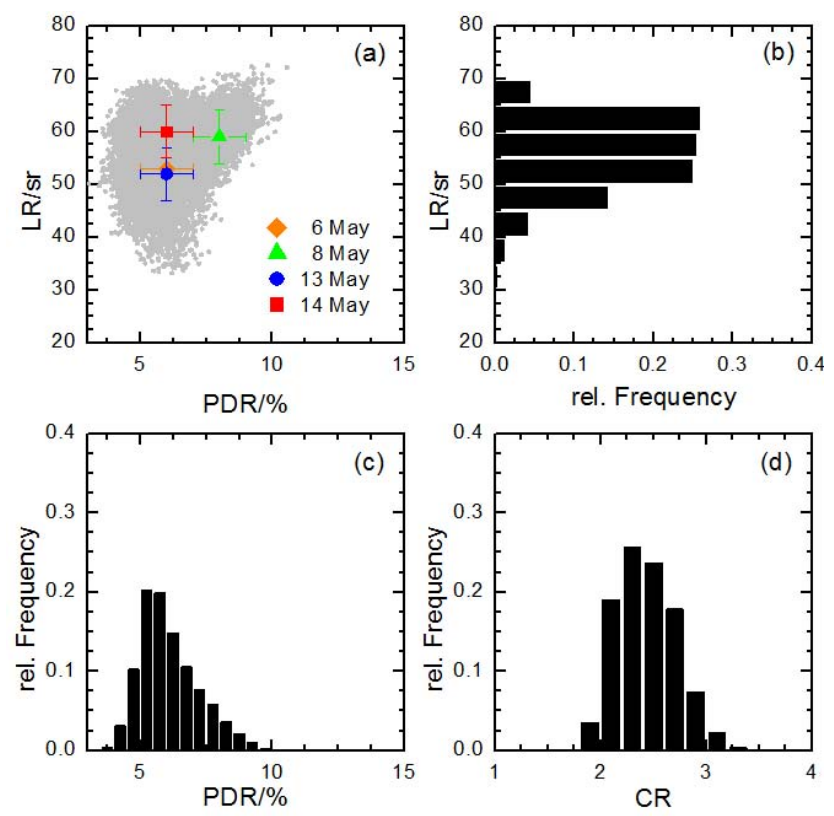

Fig. 8. (a) Scatterplot of lidar ratio (LR) vs. particle linear depolarisation ratio (PDR) (both at $532 \mathrm{~nm}$ ) for measurements within pollution aerosol layers during the first half of the EUCAARILONGREX campaign. The grey dots show all lidar measurement points within pollution layers, the colour-coded squares show the mean values within the pollution layers for the different measurement days summarized in Table 2. (b) and (c) show the frequency distribution of the lidar ratio (LR) and the particle linear depolarisation ratio (PDR) at $532 \mathrm{~nm}$, respectively, for all considered measurements during the first half of the EUCAARI-LONGREX campaign. (d) Frequency distribution of the colour ratio (CR) for all considered measurements during the first half of the EUCAARI-LONGREX campaign.

points considered as pollution aerosols. The colour coded measurement points show the mean values for the individual measurement days.

Figure $8 b$ and $c$ show the corresponding histograms of the observed lidar ratio and the particle linear depolarisation ratio, respectively. Obviously, the most frequent value pairs are within a range of the particle linear depolarization ratio of
$5-7 \%$ and a range of the lidar ratio of $50-60 \mathrm{sr}$. $50 \%$ of all measurement points show values of the particle linear depolarization ratio between $5 \%$ and $7 \%$ and a lidar ratio between 51 and $61 \mathrm{sr}$, and about $90 \%$ of all measurement points show values between $4 \%$ and $8 \%$ of the particle linear depolarization ratio and between $48 \mathrm{sr}$ and $65 \mathrm{sr}$ of the lidar ratio. The median of the particle linear depolarization ratio is $6 \%$, of the lidar ratio $56 \mathrm{sr}$. Lidar ratios around and below $40 \mathrm{sr}$, found for about $5 \%$ of all measurement points, may either indicate rural particles (Evans, 1988; Anderson et al., 2000) or mixtures with other aerosol types (e.g. clean continental aerosol or marine aerosol).

But not only the lidar ratio and the particle linear depolarisation ratio are only dependent on the aerosol type. Also the colour ratio (CR), i.e. the ratio of the particle backscatter coefficients at $532 \mathrm{~nm}$ and at $1064 \mathrm{~nm}$, is independent of the aerosol concentration. As it is directly related to the Angström exponent $\mathrm{AE}(\mathrm{AE}=-\ln (\mathrm{CR}) / \ln (532 / 1064))$ it provides information about the particle size. As a rule of thumb colour ratios around one indicate large particles (e.g. dust - Tesche et al., 2009), while colour ratios around two and higher are an indication for small particles compared to the lidar wavelength (e.g. smoke - Ansmann et al., 2009). For the layers of pollution aerosol observed during the first half of the EUCAARI-LONGREX campaign, a mean colour ratio of 2.4 was found, indicating small, submicron particles. More than $85 \%$ of all data points show a colour ratio between 2.0 and 2.8 , and less than $3.7 \%$ show colour ratios lower than 2.0 (see Fig. 8d); an indication that no large particles were present.

\subsection{Discussion}

The characterization of polluted air masses is an active research topic concerning air quality and climate effect. Therefore a number of several papers report about measurements within polluted air masses. Lidar ratios of pollution aerosols over Central Europe were reported by Wandinger et al. (2002). They found values of $50-65 \mathrm{sr}$ at $532 \mathrm{~nm}$ from Raman lidar measurements. Ansmann et al. (2000) found lidar ratios of $60-90 \mathrm{sr}$ in polluted aerosol layers over 
India, measured with a Raman lidar system during the field campaign INDOEX. Müller et al. (2001) reported about mean lidar ratios of about $60 \mathrm{sr}$ for the same measurement experiment. During the ACE-2 field campaign Raman lidar measurements in polluted aerosol layers over Portugal showed lidar ratios of 50-70 sr (Ansmann et al., 2001). Xie et al. (2008) found values of $61 \mathrm{sr} \pm 14 \mathrm{sr}$ in moderately polluted aerosol layers over Beijing, China. Hänel et al. (2012) found lidar ratios around $60 \mathrm{sr}$ in pollution layers in and near Beijing, and Chen et al. (2012) found a mean value of the lidar ratio of about $58 \mathrm{sr}$ in the Pearl River Delta. Using a $180^{\circ}$ backscatter nephelometer lidar ratios of $64 \mathrm{sr} \pm 4 \mathrm{sr}$ for pollution aerosol over Illinois (Anderson et al., 2000), and 60$70 \mathrm{sr}$ for continental aerosols were observed (Doherty et al., 1999). Inversions from AERONET (Holben et al., 1998) sunphotometer measurements resulted in values of $71 \mathrm{sr} \pm 10 \mathrm{sr}$ for industrial pollution over Europe, and over Middle and North America (Cattrall et al., 2005). Measurements over South-East Asia resulted in values of $58 \mathrm{sr} \pm 10 \mathrm{sr}$ for industrial pollution aerosols (Cattrall et al., 2005). While a number of papers deal with the lidar ratio of industrial pollution or urban haze, measurements of the particle linear depolarisation ratio of this aerosol type are rare. Müller et al. (2007) reported about particle linear depolarisation ratios for urban haze of about or lower $5 \%$ over Central and South-West Europe, and over North America. Burton et al. (2012) found values between $2-11 \%$ over North America. In polluted air masses over Beijing, China, mean values of the particle linear depolarisation ratio of $7 \%$ were found (Xie et al., 2008). Our values of $56 \mathrm{sr} \pm 6 \mathrm{sr}$ and $6 \% \pm 1 \%$ for pollution aerosols agree well with former findings.

\section{Summary and conclusion}

During EUCAARI-LONGREX both the meteorological conditions and the flight strategy were best suited to study pollution aerosols with respect to location and age of the aerosols. The meteorological conditions were determined by a persistent high pressure system over the North Sea during the first half of the observing period and northerly advection during the second half. Especially during the first half high aerosol optical depth (AOD) values were observed due to the buildup of a pollution layer in the absence of precipitation. A total of 15 Falcon flight missions with 48 flight hours were performed. The measurements included observations with an airborne HSRL to characterize the optical properties and the spatial distribution of pollution aerosol. HSRL measurements are an excellent tool to characterize aerosols, as they provide high-resolved temporal and vertical information on the aerosol distribution and aerosol optical properties with a high accuracy. The main goal of this study was to determine lidar derived optical properties for European pollution aerosols, in particular the particle linear depolarization ratio and the lidar ratio. Both quantities are independent from the aerosol load and, in combination, have the potential to distinguish different aerosol types as was recently shown by Groß et al. $(2011,2012)$ and Burton et al. (2012).

During all measurements included into this study, pollution aerosols over and from different locations across $\mathrm{Eu}-$ rope and of different age could be observed (Hamburger et al., 2012). Over all, the measurements of the lidar ratio and the particle linear depolarization ratio of pollution aerosols showed a narrow range of values. The lidar ratio ranged between $48-65 \mathrm{sr}$ in $90 \%$ of the measurements points. For the particle linear depolarization ratio values between 4 and $8 \%$ were found for $90 \%$ of all measurement points. Based on our observations, the mean lidar ratio of the pollution aerosol is $56 \mathrm{sr} \pm 6 \mathrm{sr}$. The mean depolarisation ratio is $6 \% \pm 1 \%$. These results are in very good agreement to former findings. This is in particular valuable to define an aerosol type "pollution aerosol", and to determine the right input parameter for aerosol retrievals, e.g. of satellite instruments such as on CALIPSO. Furthermore, the characterization of the aerosol type "pollution aerosol" is valuable to distinguish pollution aerosol from other aerosol types and to determine mixtures with other types of aerosols.

Acknowledgements. This work has been partly funded by EUCAARI (European Integrated project on Aerosol Cloud Climate and Air Quality interactions) No. 036833-2, and by the Deutsche Forschungsgemeinschaft (DFG) within the HALO-SPP No. 1294/2. The authors like to thank the staff members of the DLR Falcon 20 from the DLR Flight operation department during the EUCAARI-LONGREX campaign. Especially, we want to thank Thomas Hamburger for the help with the meteorological description and the trajectory analysis.

The service charges for this open access publication have been covered by a Research Centre of the Helmholtz Association.

Edited by: T. Petäjä

\section{References}

Ackermann, J.: The extinction-to-backscatter ratio of tropospheric aerosol: A numerical study, J. Atmos. Ocean. Tech., 15, 10431050, doi:10.1175/1520-0426, 1998.

Anderson, T. L., Masonis, S. J., Covert, D. S., Charlson, R. J., and Rood, M. J.: In situ measurement of the aerosol extinction-tobackscatter ratio at a polluted continental site, J. Geophys. Res., 105, 26907-26915, doi:10.1029/2000JD900400, 2000.

Ansmann, A., Althausen, D., Wandinger, U., Franke, K., Müller, D., Wagner, F., and Heintzenberg, J.: Vertical profiling of the Indian aerosol plume with six-wavelength lidar during INDOEX: A first case study, Geophys. Res. Lett., 27, 963-966, doi:10.1029/1999GL010902, 2000.

Ansmann, A., Wagner, F., Althausen, D., Müller, D., Herber, A., and Wandinger, U.: European pollution outbreaks during ACE 2: Lofted aerosol plumes observed with Raman lidar at 
the Portuguese coast, J. Geophys. Res., 106, 20725-20733, doi:10.1029/2000JD000091, 2001.

Ansmann, A., Baars, H., Tesche, M., Müller, D., Althausen, D., Engelmann, R., Pauliquevis, T., and Artaxo, P.: Dust and smoke transport from Africa to South America: Lidar profiling over Cape Verde and the amazon rainforest, Geophys. Res. Lett., 36, L11802, doi:10.1029/2009GL037923, 2009.

Burton, S. P., Ferrare, R. A., Hostetler, C. A., Hair, J. W., Rogers, R. R., Obland, M. D., Butler, C. F., Cook, A. L., Harper, D. B., and Froyd, K. D.: Aerosol classification using airborne High Spectral Resolution Lidar measurements - methodology and examples, Atmos. Meas. Tech., 5, 73-98, doi:10.5194/amt-5-73-2012, 2012.

Cattrall, C., Reagan, J., Thome, K., and Dubovik, O.: Variability of aerosol and spectral lidar and backscatter and extinction ratios of key aerosol types derived from selected Aerosol Robotic Network locations, J. Geophys. Res., 110, D10S11, doi:10.1029/2004JD005124, 2005.

Chen, Z., Liu, W., Zhang, Y., and Heese, B.: Lidar ratio of Asian haze and pollution episodes observed by using a Raman/elastic lidar, Chinese Optics Letters, 10, doi:10.3788/COL201210.S10101, S10101, 2012.

Doherty, S. J., Anderson, T. L., and Charlson, R. J.: Measurement of the lidar ratio for atmospheric aerosols with a 180 backscatter nephelometer, Appl. Opt., 38, 1823-1832, doi:10.1364/AO.38.001823, 1999.

Draxler, R. R. and Rolph, G. D.: Hysplit (HYbrid Single Particle Lagrangian Integrated Trajectory) Model, NOAA Air Resources Laboratory, Silver Spring, MD, 2012.

Esselborn, M., Wirth, M., Fix, A., Tesche, M., and Ehret, G.: Airborne high spectral resolution lidar for measuring aerosol extinction and backscatter coefficients, Appl. Opt., 47, 346-358, doi:10.1364/AO.47.000346, 2008.

Esselborn, M., Wirth, M., Fix, A., Weinzierl, B., Rasp, K., Tesche, M., and Petzold, A.: Spatial distribution and optical properties of Saharan dust observed by airborne high spectral resolution lidar during SAMUM 2006, Tellus, B61, 131-143, doi:10.1111/j.1600-0889.2008.00394.x, 2009.

Evans, B.: Sensitivity of the backscatter/extinction ratio to changes in aerosol properties: Implications for lidar, Appl. Opt., 27, 3299-3306, doi:10.1364/AO.27.003299, 1988.

Forster, P., Ramaswamy, V., Artaxo, P., Berntsen, T., Betts, R., Fahey, D. W., Haywood, J., Lean, J., Lowe, D. C., Myhre, G., Nganga, J., Prinn, R., Raga, G., Schulz, M., and Van Dorland, R.: Changes in Atmospheric Constituents and in Radiative Forcing, in: Climate Change 2007: The Physical Science Basis. Contribution of Working Group I to the Fourth Assessment Report of the Intergovernmental Panel on Climate Change, edited by: Solomon, S., Qin, D., Manning, M., Chen, Z., Marquis, M., Averyt, K. B., Tignor, M., and Miller, H. L., Cambridge University Press, Cambridge, United Kingdom and New York, NY, USA, 2007

Freudenthaler, V., Esselborn, M., Wiegner, M., Heese, B., Tesche, M., Ansmann, A., Müller, D., Althause, D., Wirth, M., Fix, A., Ehret, G., Knippertz, P., Toledano, C., Gasteiger, J., Garhammer, M., and Seefeldner, M.: Depolarization ratio profiling at several wavelengths in pure Saharan dust during SAMUM 2006, Tellus, B61, 165-179, doi:10.1111/j.1600-0889.2008.00396.x, 2009.
Groß, S., Tesche, M., Freudenthaler, V., Toledano, C., Wiegner, M., Ansmann, A., Althausen, D., and Seefeldner, M.: Characterization of Saharan dust, marine aerosols and mixtures of biomass burning aerosols and dust by means of multi-wavelength depolarization- and Raman-measurements during SAMUM-2, Tellus, B63, 706-724, doi:10.1111/j.1600-0889.2011.00556.x, 2011.

Groß, S., Esselborn, M., Weinzierl, B., Wirth, M., Fix, A., and Petzold, A.: Aerosol classification by airborne high spectral resolution lidar observations, Atmos. Chem. Phys. Discuss., 12, 25983-26028, doi:10.5194/acpd-12-25983-2012, 2012.

Hänel, A., Baars, H., Althausen, D., Ansmann, A., Engelmann, R., and Sun, J. Y.: One-year aerosol profiling with EUCAARI Raman lidar at Shangdianzi GAW station: Beijing plume and seasonal variations, J. Geophys. Res., 117, D13201, doi:10.1029/2012JD017577, 2012.

Hamburger, T., McMeeking, G., Minikin, A., Birmili, W., Dall'Osto, M., O’Dowd, C., Flentje, H., Henzing, B., Junninen, H., Kristensson, A., de Leeuw, G., Stohl, A., Burkhart, J. F., Coe, H., Krejci, R., and Petzold, A.: Overview of the synoptic and pollution situation over Europe during the EUCAARILONGREX field campaign, Atmos. Chem. Phys., 11, 10651082, doi:10.5194/acp-11-1065-2011, 2011.

Hamburger, T., McMeeking, G., Minikin, A., Petzold, A., Coe, H., and Krejci, R.: Airborne observations of aerosol microphysical properties and particle ageing processes in the troposphere above Europe, Atmos. Chem. Phys., 12, 11533-11554, doi:10.5194/acp-12-11533-2012, 2012.

Holben, B. N., Eck, T. F., Slutsker, I., Tanré, D., Buis, J. P., Setzer, A., Vermote, E., Reagan, J. A., Kaufman, Y. J., Nakajima, T., Lavenu, F., Jankowiak, I., and Smirnov, A.: AERONET - A Federated Instrument Network and Data Archive for Aerosol Characterization, Remote Sens. Environ., 66, 1-16, doi:10.1016/S0034-4257(98)00031-5, 1998.

IPCC: Climate Change 2007: The scientific basis, Cambridge University Press, 2007.

Kulmala, M., Asmi, A., Lappalainen, H. K., Carslaw, K. S., Pöschl, U., Baltensperger, U., Hov, Ø., Brenquier, J.-L., Pandis, S. N., Facchini, M. C., Hansson, H.-C., Wiedensohler, A., and O'Dowd, C. D.: Introduction: European Integrated Project on Aerosol Cloud Climate and Air Quality interactions (EUCAARI) - integrating aerosol research from nano to global scales, Atmos. Chem. Phys., 9, 2825-2841, doi:10.5194/acp-9-2825-2009, 2009.

Kulmala, M., Asmi, A., Lappalainen, H. K., Baltensperger, U., Brenguier, J.-L., Facchini, M. C., Hansson, H.-C., Hov, Ø., O’Dowd, C. D., Pöschl, U., Wiedensohler, A., Boers, R., Boucher, O., de Leeuw, G., Denier van der Gon, H. A. C., Feichter, J., Krejci, R., Laj, P., Lihavainen, H., Lohmann, U., McFiggans, G., Mentel, T., Pilinis, C., Riipinen, I., Schulz, M., Stohl, A., Swietlicki, E., Vignati, E., Alves, C., Amann, M., Ammann, M., Arabas, S., Artaxo, P., Baars, H., Beddows, D. C. S., Bergström, R., Beukes, J. P., Bilde, M., Burkhart, J. F., Canonaco, F., Clegg, S. L., Coe, H., Crumeyrolle, S., D’Anna, B., Decesari, S., Gilardoni, S., Fischer, M., Fjaeraa, A. M., Fountoukis, C., George, C., Gomes, L., Halloran, P., Hamburger, T., Harrison, R. M., Herrmann, H., Hoffmann, T., Hoose, C., Hu, M., Hyvärinen, A., Hõrrak, U., Iinuma, Y., Iversen, T., Josipovic, M., Kanakidou, M., Kiendler-Scharr, A., Kirkevåg, A., Kiss, G., 
Klimont, Z., Kolmonen, P., Komppula, M., Kristjánsson, J.-E., Laakso, L., Laaksonen, A., Labonnote, L., Lanz, V. A., Lehtinen, K. E. J., Rizzo, L. V., Makkonen, R., Manninen, H. E., McMeeking, G., Merikanto, J., Minikin, A., Mirme, S., Morgan, W. T., Nemitz, E., O’Donnell, D., Panwar, T. S., Pawlowska, H., Petzold, A., Pienaar, J. J., Pio, C., Plass-Duelmer, C., Prévôt, A. S. H., Pryor, S., Reddington, C. L., Roberts, G., Rosenfeld, D., Schwarz, J., Seland, Ø., Sellegri, K., Shen, X. J., Shiraiwa, M., Siebert, H., Sierau, B., Simpson, D., Sun, J. Y., Topping, D., Tunved, P., Vaattovaara, P., Vakkari, V., Veefkind, J. P., Visschedijk, A., Vuollekoski, H., Vuolo, R., Wehner, B., Wildt, J., Woodward, S., Worsnop, D. R., van Zadelhoff, G.-J., Zardini, A. A., Zhang, K., van Zyl, P. G., Kerminen, V.-M., S Carslaw, K., and Pandis, S. N.: General overview: European Integrated project on Aerosol Cloud Climate and Air Quality interactions (EUCAARI) - integrating aerosol research from nano to global scales, Atmos. Chem. Phys., 11, 13061-13143, doi:10.5194/acp11-13061-2011, 2011.

Müller, D., Wandinger, U., Althausen, D., and Fiebig, M.: Comprehensive Particle Characterization from Three-Wavelength Raman-Lidar Observations: Case Study, Appl. Opt., 40, 48634869, doi:10.1364/AO.40.004863, 2001.

Müller, D., Ansmann, A., Mattis, I., Tesche, M., Wandinger, U., Althausen, D., and Pisani, G.: Aerosol-type-dependent lidar ratios observed with raman lidar, J. Geophys. Res., 112, D16202, doi:10.1029/2006JD008292, 2007.

Quinn, P. K., Anderson, T. L., Bates, T. S., Dlugi, R., Heintzenberg, J., von Hoyningen-Huene, W., Kulmala, M., Russel, P. B., and Swietlicki, E.: Closure in tropospheric aerosol-climate research: A review and future needs for addressing aerosol direct short-wave radiative forcing, Contrib. Atmos. Phys., 69, 547577,1996

Shimizu, H., Lee, S., and She, C.: High spectral resolution lidar system with atomic blocking filters for measuring atmospheric parameters, Appl. Opt., 22, 1373-1381, doi:10.1364/AO.22.001373, 1983.

Shipley, S., Tracy, D., Eloranta, E., Trauger, J., Sroga, J., Roesler, F., and Weinman, J.: High spectral resolution lidar to measure optical scattering properties of atmospheric aerosols. 1: Theory and instrumentation, Appl. Opt., 22, 3716-3724, doi:10.1364/AO.22.003716, 1983.

Tesche, M., Ansmann, A., Müller, D., Althausen, D., Engelmann, R., Hu, M., and Zhang, Y.: Particle backscatter, extinction, and lidar ratio profiling with Raman lidar in south and north China, Appl. Opt., 46, 6302-6308, 2007.
Tesche, M., Ansmann, A., Müller, D., Althausen, D., Mattis, I., Heese, B., Freudenthaler, V., Wiegner, M., Esselborn, M., Pisani, G., and Knippertz, P.: Vertical profiling of saharan dust with Raman lidars and airborne HSRL in southern Morocco during SAMUM, Tellus, B61, 144-164, doi:10.1111/j.16000889.2008.00390.x, 2009.

Wandinger, U., Müller, D., Böckmann, C., Althausen, D., Matthias, V., Bösenberg, J., Weiß, V., Fiebig, M., Wendisch, M., Stohl, A., and Ansmann A.: Optical and microphysical characterization of biomass-burning and industrial-pollution aerosols from multiwavelength lidar and aircraft measurements, J. Geophys. Res., 117, 8125, doi:10.1029/2000JD000202, 2002.

Wandinger, U., Tesche, M., Seifert, P., Ansmann, A., Müller, D., and Althausen, D.: Size matters: Influence of multiple scattering on CALIPSO light-extinction profiling in desert dust, Geophys. Res. Lett., 37, L10801, doi:10.1029/2010GL042815, 2010.

Wernli, B. H. and Davies, H. C.: A lagrangian-based analysis of extratropical cyclones. I: The method and some applications, Q. J. Roy. Meteorol. Soc., 123, 467-489, doi:10.1002/qj.49712353811, 1997.

Wernli, H.: A lagrangian-based analysis of extratropical cyclones. II: A detailed case-study, Q. J. Roy. Meteorol. Soc., 123, 16771706, doi:10.1002/qj.49712354211, 1997.

Winker, D. M., Hunt, W. H., and McGill, M. J.: Initial performance assessment of CALIOP, Geophys. Res. Lett., 34, L19803, doi:10.1029/2007GL030135, 2007.

Wirth, M., Fix, A., Mahnke, P., Schwarzer, H., Schrandt, F., and Ehret, G.: The airborne multi-wavelength H2O-DIAL WALES: system design and performance, Appl. Phys. B, 96, 201-213, doi:10.1007/s00340-009-3365-7, 2009.

Xie, C., Nishizawa, T., Sugimoto, N., Matsui, I., and Wang, Z.: Characteristics of aerosol optical properties in pollution and Asian dust episodes over Beijing, China, Appl. Opt., 47, 49454951, doi:10.1364/AO.47.004945, 2008.

Zieger, P., Weingartner, E., Henzing, J., Moerman, M., de Leeuw, G., Mikkilá, J., Ehn, M., Petäjä, T., Clémer, K., van Roozendael, M., Yilmaz, S., Frieß, U., Irie, H., Wagner, T., Shaiganfar, R., Beirle, S., Apituley, A., Wilson, K., and Baltensperger, U.: Comparison of ambient aerosol extinction coefficients obtained from in-situ, MAX-DOAS and LIDAR measurements at Cabauw, Atmos. Chem. Phys., 11, 2603-2624, doi:10.5194/acp11-2603-2011, 2011. 